(2) Open Access Full Text Article

RETRACTION

\title{
An unusual case of spontaneous Mycobacterium chelonae corneal ulcer in a healthy middle-aged adult [Retraction]
}

Bhandari V, Sriganesh R, Relekar K. An unusual case of spontanous Mycobacterium chelonae corneal ulcer in a healthy middle-aged adult. Int Med Case Rep J. 2016;9: 121-124.

The Editor-in-Chief and Publisher have retracted this paper because of duplicate publication in Case Reports in Ophthalmological Medicine on June 20, 2015. peer-reviewed open-access journal publishing original case reports from all medical specialties. Previously unpublished medical posters are also accepted relating to any area of clinical or preclinical science. Submissions should not normally exceed 2,000 words or

4 published pages including figures, diagrams and references. The manuscript management system is completely online and includes a very quick and fair peer-review system, which is all easy to use. Visit http://www.dovepress.com/testimonials.php to read real quotes from published authors. 